\title{
Density-dependent indirect effects: apparent mutualism and apparent competition coexist in a two-prey system
}

\author{
W. Christopher Long ${ }^{1,2, *}$, Emily F. Gamelin ${ }^{1,3}$, Eric G. Johnson ${ }^{1}$, Anson H. Hines ${ }^{1}$ \\ ${ }^{1}$ Smithsonian Environmental Research Center, 617 Contees Wharf Road, Edgewater, Maryland 21037, USA \\ ${ }^{2}$ Present address: Kodiak Laboratory, Resource Assessment and Conservation Engineering Division, \\ Alaska Fisheries Science Center, National Marine Fisheries Service, NOAA, 301 Research Ct., Kodiak, Alaska 99615, USA \\ ${ }^{3}$ Present address: National Oceanic and Atmospheric Administration, Office of Oceanic and Atmospheric Research (OAR), \\ 1315 East-West Highway, Silver Spring, Maryland 20910, USA
}

\begin{abstract}
A predator consuming multiple prey species usually causes indirect effects. Apparent mutualism results when multiple prey species reduce predation risk for each other by altering a predator's functional response. Short-term apparent competition occurs when multiple prey species increase predation risks for each other through the numerical response, i.e. increasing the predator's birth rate, or aggregative response, i.e. attracting a higher density of predators. Our objectives in this study were to determine the aggregative response and 2-prey functional response of a predator and to examine indirect effects over a range of prey densities. We used the clam Macoma balthica and juvenile blue crabs Callinectes sapidus as prey for adult blue crabs. In laboratory experiments, we determined the single-prey functional responses of the crabs to each prey species and the 2-prey functional response. We combined the 2-prey functional response with the known blue crab aggregative response to clams to estimate field predation rates. Our model predicts that at low prey densities, clams and juvenile blue crabs exhibit apparent mutualism, whereas at high clam densities, this relation switches to short-term apparent competition. These unexpected results highlight the need to incorporate multiple aspects of predation at multiple scales when considering indirect effects.
\end{abstract}

KEY WORDS: Predator-prey interactions $\cdot$ Functional response $\cdot$ Indirect effects $\cdot$ Blue crab Macoma balthica

Resale or republication not permitted without written consent of the publisher

\section{INTRODUCTION}

\section{Predator-prey interactions and indirect effects}

Indirect effects of species interactions are prevalent in food webs and can be more important to predator-prey dynamics than direct effects (Wootton 1994, Menge 1995, Kaplan \& Denno 2007). Indirect effects can occur when a predator feeds on multiple prey species (Holt \& Lawton 1994). Two of the most common indirect effects are apparent mutualism and apparent competition. Apparent mutualism gener- ally occurs in a 2-prey system when a predator consumes fewer of each species than it would in a 1-prey system because the predator divides its foraging time between the 2 species, thus changing the predator's functional response (Colton 1987). If this response is one-way, it is known as apparent commensalism. Apparent commensalism can help stabilize predatorprey interactions (Oaten \& Murdoch 1975) because it can change a Type II or destabilizing functional response to a Type III or stabilizing functional response (Holling 1959, Hassell et al. 1977). Apparent competition occurs when the presence of one prey species 
increases the predator density (i.e. changes either the predator's numerical or aggregative response), thus increasing predation on the other species (Holt \& Lawton 1994). This occurs either through increasing the predator population growth rate (Settle et al. 1996, Carvalheiro et al. 2008) or through a local increase in predator density due to predator movement (Holt \& Kotler 1987, Brown \& Mitchell 1989, Murakami \& Nakano 2002).

\section{Study organisms}

The blue crab Callinectes sapidus Rathbun, 1896, is an important benthic predator in Chesapeake Bay (Virnstein 1977). Large adult crabs are opportunistic omnivores, feeding primarily on bivalves $(\sim 50 \%$ of diet) and crustaceans $(\sim 30 \%)$ as well as fish and polychaetes (Hines et al. 1990). Blue crabs are cannibalistic, with adults feeding on juveniles (Hines \& Ruiz 1995). Because cannibalism represents a major source of mortality for juvenile blue crabs, juveniles congregate in shallow waters $(<1 \mathrm{~m})$, where adults are less abundant (Hines \& Ruiz 1995, Hines et al. 1995), and in structured habitats that provide a predation refuge (Everett \& Ruiz 1993).

Macoma balthica Linnaeus, 1758, is a small (shell length $<40 \mathrm{~mm}$ ) tellinid clam that is the dominant biomass in unvegetated mud habitats within the mesohaline regions of Chesapeake Bay (Holland et al. 1977) and is a major source of food for blue crabs (Baird \& Ulanowicz 1989). M. balthica avoids predation by burying deeply, up to $35 \mathrm{~cm}$, in the sediment (Hines \& Comtois 1985). The blue crab exhibits a Type III functional response to $M$. balthica in both the laboratory (Eggleston et al. 1992) and field (Seitz et al. 2001). The blue crab also exhibits a strong aggregative response to clams in general and $M$. balthica in particular (Clark et al. 1999a,b, Seitz et al. 2008). Indeed, clam density explains $93 \%$ of the variance of large crab density (Seitz et al. 2003). Hereafter, references to clams will imply $M$. balthica.

\section{Study aims}

In the present study, our objectives were to define the 2-prey functional response of adult blue crabs to clams and juvenile blue crabs and to determine the indirect effects in this system. To determine indirect effects, it is necessary to examine both the functional response, which is the likely mechanism responsible for indirect mutualism (Colton 1987), and the numeri- cal or aggregative responses, which may lead to indirect competition (Holt \& Lawton 1994). It seems likely that the relative strength of these responses will determine whether the net indirect effect will be positive or negative (Abrams \& Matsuda 1996). While many studies have examined either the predator functional, numerical, or aggregative response in a system (e.g. Colton 1987, Settle et al. 1996, Rott et al. 1998, Murakami \& Nakano 2002), few studies have integrated these responses because of the differences in temporal and spatial scales (Tschanz et al. 2007). The functional response operates on a small spatial and temporal scale as it addresses predator feeding in a local prey patch over a short time period. The numerical and aggregative responses operate over a longer time scale and a larger area as they deal with increases in predator populations over generations or the movement of predators among foraging areas. We used a series of predation experiments to determine both the single-species and the 2-species functional responses of adult blue crabs to clams and juvenile blue crabs. We then modeled field predation rates by combining the 2-prey functional response with the known predator aggregative response to estimate the indirect effect of clams on the predation risk for juvenile blue crabs in the field. By combining processes that occur at multiple scales, we were able to identify indirect effects in this system over a wide range of prey densities and gain a more holistic understanding of the interactions between these species.

\section{MATERIALS AND METHODS}

\section{Laboratory setup}

All of the functional response experiments were performed at the Smithsonian Environmental Research Center (SERC) wet laboratory. Experimental trials were conducted in $1 \times 2 \mathrm{~m}$ tanks with flowthrough water from the Rhode River (Chesapeake Bay, Maryland, USA). Each tank was divided into 2 sections $\left(1 \mathrm{~m}^{2}\right)$ with plastic Vexar ${ }^{1}$ barrier (DuPont) mesh. Replicates within each experiment were randomly assigned to tanks and were run in both sections simultaneously. The tanks were filled with $12.5 \mathrm{~cm}$ of sand collected from Canning House Bay within the Rhode River. The water temperatures were $22.2 \pm 3.3^{\circ} \mathrm{C}$ (standard deviation, SD), and the salinities were 12.2 \pm 1.7 (YSI Model 85).

\footnotetext{
${ }^{1}$ Use of trade names does not imply endorsement by the National Marine Fisheries Service, NOAA
} 
Large Callinectes sapidus, with a mean carapace width (CW) of $145 \pm 13 \mathrm{~mm}$, were collected from the Rhode River using an otter trawl (3 m mouth, $50 \mathrm{~mm}$ mesh, and $7 \mathrm{~mm}$ bag liner) for use as predators. The predator's CW did not vary among treatments (ANOVA, $F_{22,76}=1.10, p=0.371$ ). Prior to use in experimental trials, the predators were held in tanks with flowing water and fed ad libitum with a commercial shrimp diet (Ziegler). Crabs were starved for $24 \mathrm{~h}$ prior to use to standardize hunger levels; blue crabs evacuate their guts within $18 \mathrm{~h}$ (McGaw \& Reiber 2000). Each crab was only used once. Clams, with an average shell length (SL) of $25.6 \pm 5.0 \mathrm{~mm}(\mathrm{SD})$, were collected from the Rhode River with a suction sampler and were kept in flowing water until used. The average SL in each trial did not differ among treatments (Kruskal-Wallis test statistic $=20.9, \mathrm{p}=0.231$ ). Juvenile C. sapidus prey (CW $26.1 \pm 5.4 \mathrm{~mm}$ ) were provided by the Center for Marine Biotechnology's hatchery program (Zmora et al. 2005), held in tanks with flowing water, and fed ad libitum with a pelleted shrimp diet (Zmora et al. 2005). The average CW in each trial did not differ among treatments (KruskalWallis test statistic $=22.1, p=0.139$ ). In the field, predation rates on hatchery crabs are the same as those on wild crabs, so the use of hatchery crabs is not expected to bias our results (Johnson et al. 2011).

For each experimental trial, the prey were established in the tank at the treatment-specific density and given time to bury and acclimate (clams: $24 \mathrm{~h}$; juvenile Callinectes sapidus: $1 \mathrm{~h}$ ). Following this time, a single adult blue crab predator was introduced into the tank. The crab was allowed to feed for $24 \mathrm{~h}$ and was then removed. At the conclusion of the trial, the sediment was sieved to collect and enumerate all remaining prey.

\section{Single-species functional responses}

We determined the functional response of crabs feeding on clams and juvenile blue crabs by performing feeding experiments at a range of prey densities (the number of replicates at each density are given in parentheses) — clams: 2 (2), 5 (6), 10 (5), 15 (5), 20 (8), and 40 (2) individuals $\mathrm{m}^{-2}$ i juvenile Callinectes sapidus: 3 (4), 5 (9), 8 (4), 10 (6), 15 (3) individuals $\mathrm{m}^{-2}$. We used maximum-likelihood estimation to fit the data to a Type I $\left(P_{\mathrm{P}}=m\right)$, II $\left(P_{\mathrm{P}}=a /\left[1+a T_{\mathrm{h}} N\right]\right)$, or III $\left(P_{\mathrm{P}}=u N /\left[1+v N+u T_{\mathrm{h}} N^{2}\right]\right)$ functional response model, where $P_{\mathrm{P}}$ is the proportional predation per predator (i.e. the number of prey eaten per predator divided by the initial number available), $m$ is the con- stant proportion of prey eaten at any prey density under a Type I functional response, $N$ is the number of prey available, $a$ is the instantaneous attack rate, and $T_{\mathrm{h}}$ is the handling time. In a Type III functional response, the equation is identical to a Type II model except that $a$ is modeled as a function of prey density such that $a_{1}=\left(u_{1} N_{1}\right) /\left(1+v_{1} N_{1}\right)$, where $u$ and $v$ are parameters defining the instantaneous attack rate (Eggleston et al. 1992). We fit the number of prey eaten to the models using a binomial distribution, where $P_{\mathrm{P}}$ is the probability of being eaten, and $N$ is the number of prey available in each trial. We selected the best model using the Akaike's information criterion (AIC) corrected for a small sample size $\left(\mathrm{AIC}_{\mathrm{c}}\right)$ for each model (Burnham \& Anderson 2002). In this and all similar analyses, we considered models with $\mathrm{AIC}_{\mathrm{c}}$ values differing by $<2$ to explain the data equally well (Burnham \& Anderson 2002). We also calculated the $\mathrm{AIC}_{\mathrm{c}}$ weight, which is the normalized likelihood, for each model.

\section{Prey choice experiment}

We determined the predation rate of adult crabs feeding on clams and juvenile blue crabs simultaneously by performing feeding experiments at a range of prey densities with both prey present. The ratios of the abundance of clams:crabs per $\mathrm{m}^{2}$ (replication at each combination is included in parentheses) used were $5: 5(7), 10: 5(5), 15: 5(3), 20: 5(1), 5: 10(5), 10: 10$ (5), 15:10 (4), 20:10 (2), 5:15 (3), 10:15 (3), 15:15 (1), and 20:20 (1). The total prey density ranged from 10 to 40 individuals $\mathrm{m}^{-2}$. We plotted the proportion of clams available $\left(A_{M}\right)$ against the proportion of clams in the diet $\left(D_{M}\right)$ and used maximum likelihood to fit a series of models: (1) no preference (i.e. $D_{M}=A_{M}$ ), (2) preference for one prey item, and (3) prey switching. Preference was modeled as in Murdoch (1969):

$$
D_{M}=\frac{C A_{M}}{1-A_{M}+c A_{M}}
$$

where $c$ is a proportionality constant indicating predator preference. If $c>1$, then the predator prefers the focal prey (in this case, Macoma balthica), and if $c<1$, the predator prefers the alternative prey. Prey switching was modeled by making $c$ a linear function of $A_{M}$. We also fit a second set of prey preference models as in Greenwood \& Elton (1979):

$$
D_{M}=\frac{1}{1+\left(\frac{1}{c A_{M}}\right)^{b}}
$$


where $b$ indicates the degree of prey switching. When $b=1$, no switching occurs, and when $b>1$, switching occurs (Elliott 2004). We fit a model (4) where we set $b=1$ for a simple preference model and another model (5) where $b$ was allowed to vary to model prey switching. Two trials in which no prey, neither clams nor juvenile crabs, were eaten were not included because $A_{M}$ could not be calculated. We assumed a normal distribution of errors. Because the variance is not expected to be constant over the range of data, we modeled the standard deviation $(\sigma)$ as a function of $D_{M}$ such that $\sigma=\sigma_{\max } D_{M}\left(1-D_{M}\right)$, where $\sigma_{\max }$ is proportional to the maximum value of $\sigma$. This gives a hump-shaped structure to $\sigma$, so that $\sigma$ at $D_{M}=1$ and $D_{M}=0$ is 0 (as expected), and at $D_{M}=$ $0.5, \sigma$ is at its maximum value of $\sigma_{\max } / 4$. This method allowed us to account for predictable differences in variance over the range of data and is analogous to weighted least-squares regression (Quinn \& Keough 2002). We selected the best model using the $\mathrm{AIC}_{\mathrm{c}}$ of each model (Burnham \& Anderson 2002).

\section{Two-prey functional response}

We used a modified Type III functional response to model the effect of multiple prey species on the functional response. We assumed a Type III response because the crabs had a Type III response to both species in isolation (see 'Results' below), and although a Type II response can be changed to a Type III by the addition of a second prey item (Holling 1959, Akre \& Johnson 1979), there is no mechanism proposed that could change a Type III to a Type II response under such circumstances. We considered that the availability of alternative prey affects the attack rate (similar to Colton 1987):

$$
a_{1}=\frac{u_{1} N_{1}}{1+v_{1} N_{1}+w_{2,1} \frac{N_{2}}{N_{1}+N_{2}}}
$$

where $a_{1}$ is the attack rate on Species 1 (the focal prey), $N_{1}$ and $N_{2}$ are the abundances of Species 1 and $2, u_{1}$ and $v_{1}$ are parameters that modify the attack rate based on the abundance of the focal species, and $w_{2,1}$ is a parameter that modifies the attack rate on Species 1 based on the proportional abundance of Species 2 (the alternative prey). When $w$ is positive, the presence of alternative prey reduces the rate of predation, especially at lower densities of the focal prey, leading to a more pronounced Type III functional response and an extension of the low density threshold. We modeled the change of the functional response as a function of the proportional availability of the alternative prey rather than the absolute number. Using the absolute density of prey would result in a vanishingly small attack rate at high alternative prey densities regardless of the density of the focal species, which is unrealistic. Additionally, because the blue crab is a chemosensory/tactile forager, its encounter rate with a prey species will be proportional to its relative, not absolute, density. Thus, the attack rate on one species is likely to vary with the relative density of the alternative species. We used maximum likelihood to fit 4 models to the combined data from both the single and 2-prey predation experiment ( $\mathrm{n}=94)$ : (1) No interaction, where neither prey influences the attack rate on the other (i.e. $W_{2,1}=$ $W_{1,2}=0$ ); (2) 2-way interaction, in which both prey influence the attack rate on the other such that $w_{2,1}>0$ and $w_{1,2}>0$; (3) and (4) 1-way interactions in which one species influences the attack rate on the other (i.e. $w_{i, j}>0$ and $w_{j, i}=0$ ). We fit the number of prey eaten to the models using a binomial distribution where $P_{\mathrm{P}}$ was the probability of being eaten and $N$ was the number of prey available in each trial. We selected the best model using the $\mathrm{AIC}_{\mathrm{c}}$ of each model (Burnham \& Anderson 2002).

\section{Modeling field predation rates on juvenile blue crabs}

Clam density was an excellent predictor of blue crab density, explaining $93 \%$ of the variation in adult blue crab density (Seitz et al. 2003). We used the known aggregative response of blue crabs to clams (Seitz et al. 2003) to estimate the density of large blue crabs over a range of clam densities; note that this equation does not include small crabs, such as those used as prey in this experiment:

$$
\text { Crabs m }{ }^{-2}=\frac{5.99+1.98 \mathrm{e}^{0.006 \text { Clams m}^{-2}}}{66}
$$

We then incorporated this relationship into our 2-prey functional response model by multiplying the density of predators by the functional response, which gives the per-predator predation rate, to predict the predation risk of juvenile blue crabs in the field over a range of prey densities. We modeled the predation risk over 1 to $20 \mathrm{crabs} \mathrm{m}^{-2}$ and 0 to 300 clams m $\mathrm{m}^{-2}$. The range of clam and juvenile crab densities is well within those in Chesapeake Bay (Orth \& van Monfrans 1987, Seitz et al. 2001, 2008), and the range of predator crab densities is 0.12 to 0.27 individuals $\mathrm{m}^{-2}$, which is lower than that used in the laboratory predation experiment. 


\section{RESULTS}

\section{Single-species functional response}

Adult blue crabs exhibited a Type III functional response to both clams and juvenile blue crabs (Table 1, Fig. 1). The evidence for a Type III functional response to juvenile blue crabs was strong, with the Type III having an $\mathrm{AIC}_{\mathrm{c}}$ weight of 1.00 (Table 1). The evidence for a Type III functional response to clams was also very strong, with a weight of 0.99. In both cases, the $\Delta \mathrm{AIC}_{\mathrm{c}}$ for the next best model was $>10$, indicating no support for the other models. We observed predator satiation in both cases, with the number of prey eaten leveling at high prey densities and the proportion eaten declining (Fig. 1).

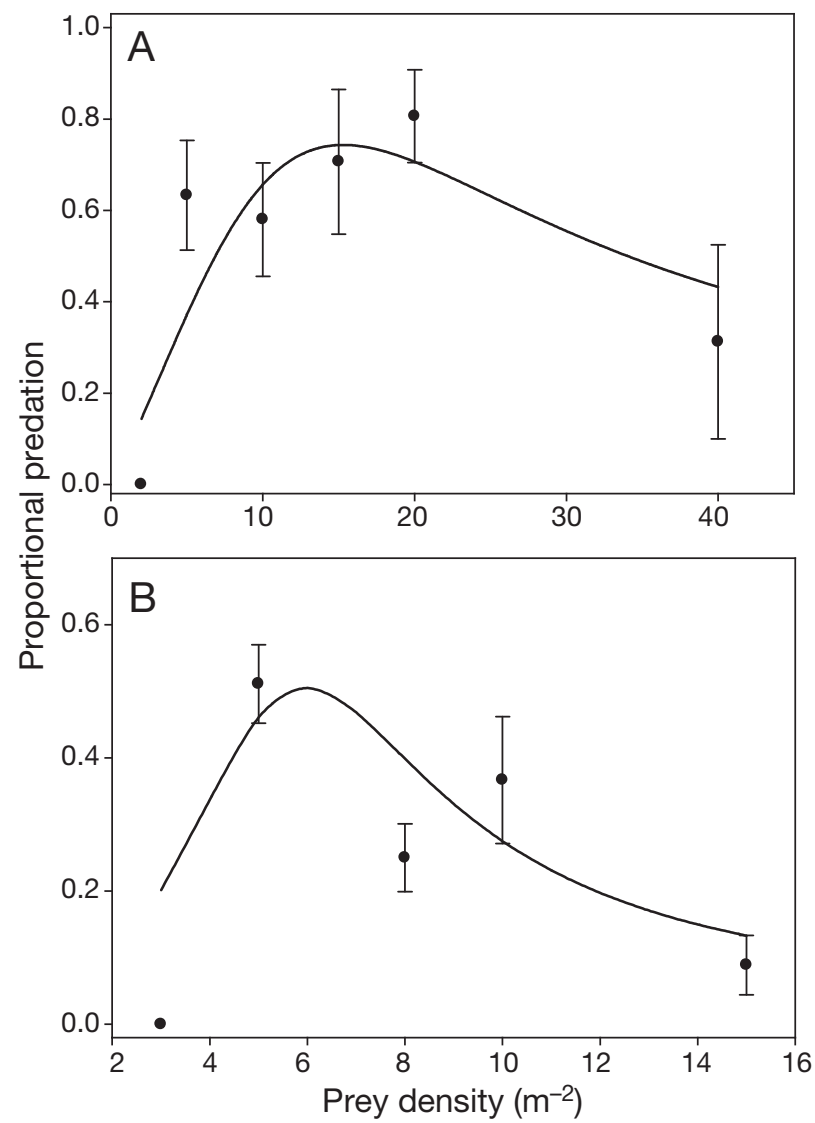

Fig. 1. Callinectes sapidus response to Macoma balthica and juvenile Callinectes sapidus. Single-species functional response of blue crabs to (A) clams ( $\mathrm{n}=28)$ and (B) juvenile blue crabs $(\mathrm{n}=26)$. Points are the average predation at each density $\pm 1 \mathrm{SE}$. Lines represent the maximum likelihood estimates for a Type III functional response. Maximum likelihood parameter estimates $( \pm 1 \mathrm{SE}$; see 'Materials and methods: Single-species functional responses' for definitions): (A) clam: $u=0.067 \pm 0.025, v=-0.040 \pm 0.027, T_{\mathrm{h}}=0.063 \pm$ $0.016, \mathrm{R}^{2}=0.21$; (B) juvenile blue crabs: $u=0.028 \pm 0.006$, $V=-0.28 \pm 0.026, T_{\mathrm{h}}=1.02 \pm 0.22, \mathrm{R}^{2}=0.40$
Table 1. Ranking of single-species functional response models with clams Macoma balthica and juvenile blue crabs Callinectes sapidus as prey using $\mathrm{AIC}_{\mathrm{c}}$. See 'Materials and methods: Single-species functional responses' for model descriptions

\begin{tabular}{|lcrrrr|}
\hline Model & $\begin{array}{c}\text { Para- } \\
\text { meters }\end{array}$ & $\mathrm{AIC}_{\mathrm{c}}$ & $\Delta \mathrm{AIC}_{\mathrm{c}}$ & $\begin{array}{c}\text { Likeli- } \\
\text { hood }\end{array}$ & $\begin{array}{c}\mathrm{AIC}_{\mathrm{c}} \\
\text { weights }\end{array}$ \\
\hline Clams & & & & & \\
Type III & 3 & 236.84 & 0.00 & 1.00 & 1.00 \\
Type I & 2 & 259.41 & 22.57 & 0.00 & 0.00 \\
Type II & 1 & 266.94 & 30.10 & 0.00 & 0.00 \\
Juvenile blue crabs & & & & \\
Type III & 3 & 89.47 & 0.00 & 1.00 & 0.994 \\
Type I & 2 & 100.10 & 10.63 & 0.00 & 0.005 \\
Type II & 1 & 103.05 & 13.58 & 0.00 & 0.001 \\
\hline
\end{tabular}

\section{Predator choice experiment}

Adult blue crabs did not exhibit prey switching in the choice experiments. The crabs may have had a slight preference for clams (Fig. 2), although this model had only slightly more weight than the nopreference model (Table 2), indicating that the data cannot be used to distinguish between the 2 models. Models from Murdoch (1969) did marginally better than those from Greenwood \& Elton (1979), though the $\Delta \mathrm{AIC}_{\mathrm{c}}$ were $<2$, indicating equal support. We present the best fit Murdoch preference model and the no-preference model in Fig. 2 and conclude that the adult crabs may exhibit a slight preference for clams, although the support for this is ambiguous.

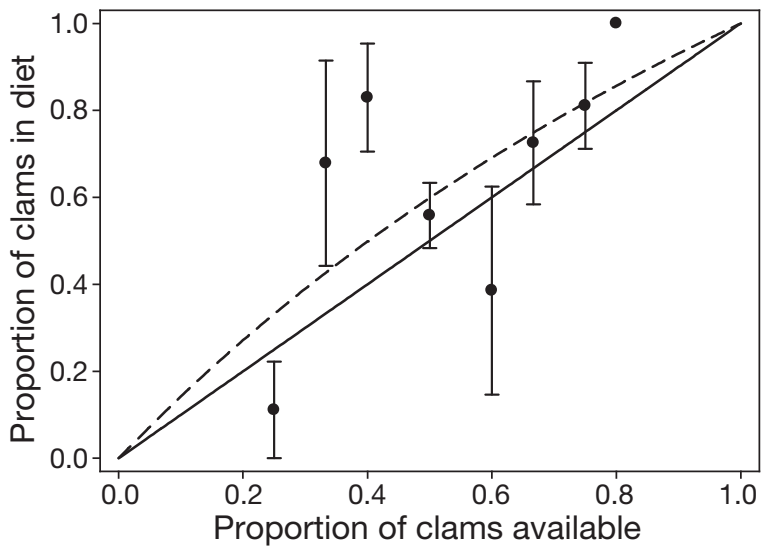

Fig. 2. Macoma balthica. Proportion of clams in the diet of crabs in predator choice experiments $(n=38)$. Points are the average predation at each density $( \pm 1 \mathrm{SE})$. Lines represent the model of no predator preference (solid line) and the maximum likelihood estimates for the predator preference model (dashed line). The maximum likelihood estimate for $C_{1}$ the predator preference parameter, is $1.47 \pm 0.37$ 
Table 2. Ranking of prey choice models and 2-prey functional response models with clams $(M)$ and juvenile blue crabs $(C)$ as prey using $\mathrm{AIC}_{\mathrm{c}}$. In prey choice models, M: models after Murdoch (1969); G: models after Greenwood \& Elton (1979). See 'Materials and methods: Two-prey functional response' for detailed model descriptions

\begin{tabular}{|lccccc|}
\hline Model & $\begin{array}{c}\text { Para- } \\
\text { meters }\end{array}$ & AICc & $\Delta \mathrm{AIC}_{\mathrm{c}}$ & $\begin{array}{c}\text { Likeli- } \\
\text { hood }\end{array}$ & $\begin{array}{c}\mathrm{AIC}_{\mathrm{c}} \\
\text { weights }\end{array}$ \\
\hline Prey choice models & & & & & \\
Preference (M) & 2 & 27.39 & 0.00 & 1.00 & 0.33 \\
No preference & 1 & 27.63 & 0.24 & 0.89 & 0.29 \\
Preference (G) & 2 & 28.85 & 1.46 & 0.48 & 0.16 \\
Switching (M) & 3 & 29.62 & 2.23 & 0.33 & 0.11 \\
Switching (G) & 3 & 29.63 & 2.24 & 0.33 & 0.11 \\
2-prey functional response models & & & \\
2-way interaction & 8 & 918.43 & 0.00 & 1.00 & 0.58 \\
C-M interaction & 7 & 919.07 & 0.64 & 0.73 & 0.42 \\
$M-C$ interaction & 7 & 931.42 & 12.99 & 0.00 & 0.00 \\
No interaction & 6 & 932.12 & 13.68 & 0.00 & 0.00 \\
\hline
\end{tabular}

salism. Both the no-interaction and the clam-crab interaction models had $\mathrm{AIC}_{\mathrm{C}}$ weights of $<0.01$. The presence of clams reduced proportional predation on juvenile blue crabs by up to 0.14 , or $50 \%$, in the most likely model compared to the predicted predation with no clams present (Fig. 3A). Likewise, the presence of juvenile blue crabs reduced proportional predation on clams by up to 0.32 , or $52 \%$, compared to the predicted predation when no crabs were present (Fig. 3B). In neither species was there evidence of a qualitative change in the functional response; the response remained a Type III under all conditions, as evidenced by the shape of the functional response curve. The predation rate increased with prey density at low prey densities, indicating a Type III response, rather than decreasing, which would indicate a Type II response (Taylor \& Eggleston 2000). The estimated handling time for clams was about half of that for juvenile blue crabs, and the attack rate was higher under almost all conditions, resulting in a greater consumption rate of clams than juvenile blue crabs at the same prey density.

\section{Modeling field predation rates on juvenile blue crabs}

Our model predicts that the predation risk for juvenile blue crabs is lowest at an intermediate clam density (Fig. 4). When clams are absent, a high
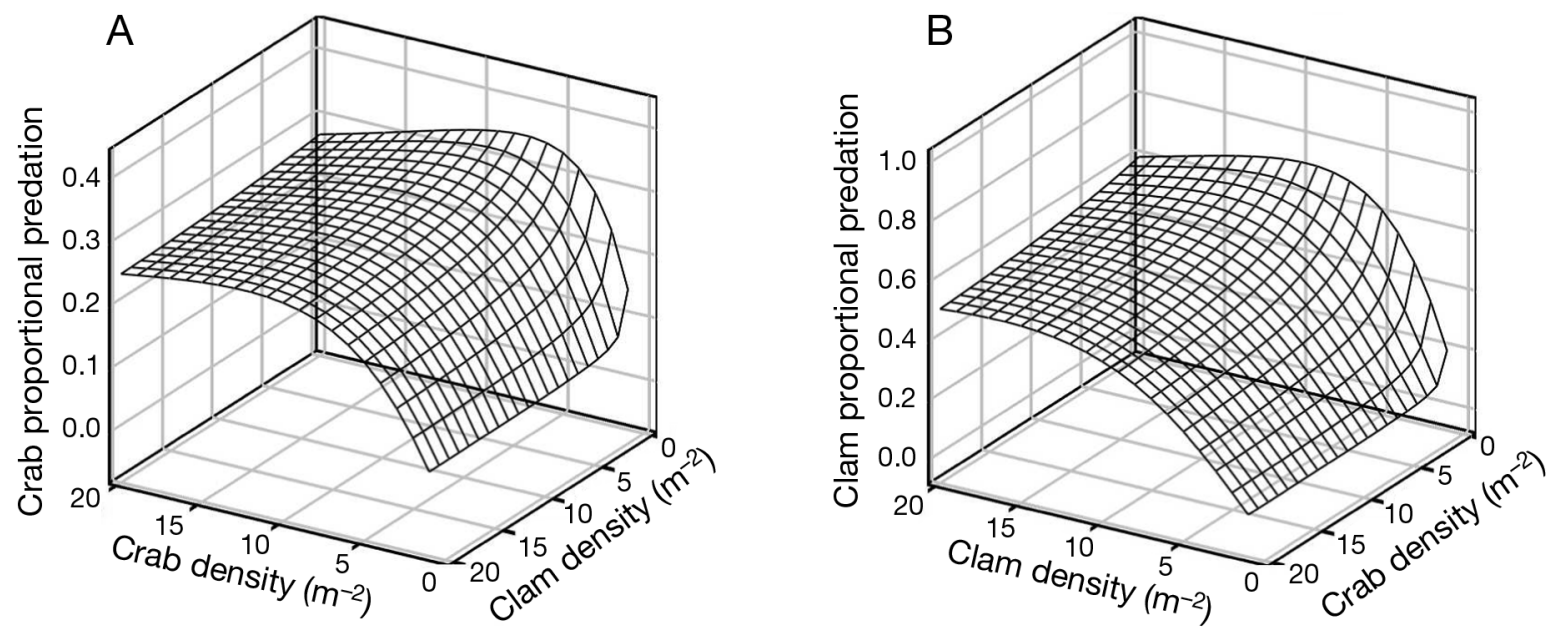

Fig. 3. Two-prey functional response surfaces for (A) juvenile blue crabs Callinectes sapidus and (B) clams Macoma balthica as predicted using the 2-way interaction model. Maximum-likelihood parameter estimates $( \pm 1 \mathrm{SE})$ as follows: (A) juvenile blue crabs: $u=0.18 \pm 0.023, v=0.24 \pm 0.69, T_{\mathrm{h}}=0.10 \pm 0.13, w_{2,1}=2.16 \pm 2.95, \mathrm{R}^{2}=0.33$; (B) clams: $u=0.21 \pm 0.09, v=0.087 \pm$ $0.105, T_{\mathrm{h}}=0.051 \pm 0.013, w_{2,1}=2.34 \pm 1.16, \mathrm{R}^{2}=0.41$ 
proportional predation is predicted because, in the absence of alternative prey, predators focus their efforts on juvenile crabs. However, high clam densities attract more predators through an aggregative response (Clark et al. 1999a, Seitz et al. 2003), resulting in increased proportional predation on juvenile crabs (Fig. 4A). This increase can be as much as $95 \%$ compared to the predation rate when there are no clams present, translating into 62 more crabs eaten per day per $100 \mathrm{~m}^{2}$ compared to predation rates expected at the same density in the absence of clams (Fig. 4B). At low to intermediate clam densities, the

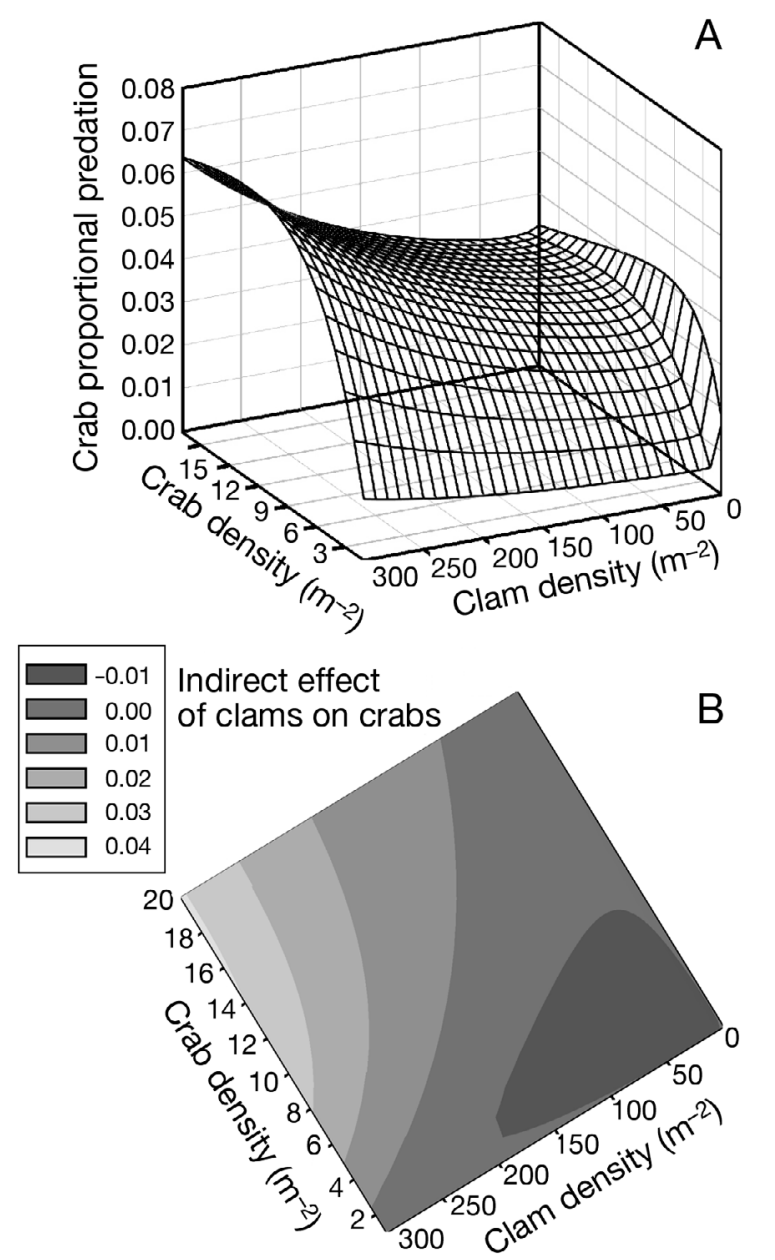

Fig. 4. Callinectes sapidus predation. (A) Daily proportional predation rate on juvenile blue crabs in the field, predicted by incorporating the predator aggregative response with the 2-prey predator functional response. (B) Contour map of the indirect effects of clam Macoma balthica populations on juvenile blue crabs. Indirect effects are calculated by subtracting the daily proportional predation rate at each point from the daily proportional predation rate at the same crab density with no clams present. Negative numbers indicate densities that result in apparent mutualism, and positive numbers indicate densities that result in short-term apparent competition clams reduce predation rates on juvenile crabs, without attracting enough predators to substantially raise the predation rate. This reduction in proportional predation is up to $48 \%$, or 5 fewer crab eaten per day per $100 \mathrm{~m}^{2}$, compared to predation rates expected at the same density in the absence of clams. The large difference in the absolute number of crabs eaten is due to the fact that the largest percentage of increase occurs at high juvenile crab densities (20 individuals $\mathrm{m}^{-2}$ ) whereas the largest percentage of decrease occurs at low juvenile crab densities (3 individuals $\mathrm{m}^{-2}$ ).

\section{DISCUSSION}

Adult blue crabs exhibited a Type III functional response to both clams and juvenile blue crabs. The presence of clams changed the predator functional response to juvenile blue crabs primarily by lowering the peak predation rate. Similarly, juvenile blue crabs altered the functional response of blue crabs to clams. Although the presence of clams lowered predation rates on juvenile blue crabs in the laboratory, the inclusion of field-based data on the predator aggregative response suggests that the lowest predation rates on juvenile blue crabs should occur at low to intermediate densities of clams in the field.

We neither saw nor expected a shift in the functional response from a Type III response in our 2-prey functional response models. Although a Type II functional response may change to a Type III with the addition of a second prey species through switching behavior (Holling 1959, Akre \& Johnson 1979), no mechanism has been proposed for a Type III changing to a Type II response. A similar reduction in predation rate with an increase of alternative prey densities without a corresponding qualitative change in the functional response can occur with predators displaying a Type II functional response (Colton 1987).

The functional response of adult blue crabs to juvenile blue crabs seemed to be dependent on the size of the juveniles. With smaller (20 to $40 \mathrm{~mm} \mathrm{CW}$ ) juvenile crabs, adults exhibit a Type III functional response (present study), but with larger (30 to $70 \mathrm{~mm}$ CW) juveniles, the functional response changes into a Type II functional response (Dittel et al. 1995). This is likely due to the relative importance of encounter (or attack) rate and handling time. With small juveniles, the predation rate is limited primarily by encounter rates, and the handling time is minimal; small crabs are more difficult to find but easier to subdue and consume. This leads to a Type III functional response (Seitz et al. 2001). With larger juve- 
niles, the predation rate is limited more by handling time, with encounter rate becoming less important; large crabs are easier to find but more difficult to subdue and consume. This leads to a Type II functional response (Seitz et al. 2001). Given the slight preference that adult blue crabs may have for clams, it is likely that the presence of clams would change the Type II functional response exhibited to larger juveniles to a Type III response (Chesson 1989), but this remains to be tested.

Clams exerted an indirect effect on juvenile blue crabs and vice versa by reducing the predation rate when available as an alternative prey (Wootton 1994). When this indirect effect is bidirectional, as is most likely in this case, it is known as apparent mutualism (e.g. Abrams 1987a,b). When it is unidirectional, as there is some support for in the present study, it is known as apparent commensalism. Such a reduction in predation with an increase in alternative prey is common (Lester \& Harmsen 2002, Heimpel et al. 2003, Rickers \& Scheu 2005), especially when the alternative prey species is preferred (Eubanks \& Denno 2000, Svenning et al. 2005, Tschanz et al. 2007). The mechanism behind this reduction is generally either predator satiation, predator switching, or preference (Murdoch 1969, Holt \& Lawton 1994, Tschanz et al. 2007), and both the first and last processes seem to be in effect in this system. However, even at high clam densities, adult crabs still preyed on juvenile crabs, indicating that if there is a preference for clams, it is weak. This result is not unexpected because crab are opportunistic omnivores and are thus likely to eat whatever they are able to find (Hines et al. 1990).

Our model predicts that clams should exert a second indirect effect on juvenile blue crabs through the predator aggregative response. In the field, adult blue crab densities are determined primarily by bivalve densities (Clark et al. 1999a, Seitz et al. 2003), indicating strong top-down control of the clam populations. Thus, high densities of clams lead to short-term apparent competition with juvenile blue crabs by increasing predator density and thus the predation rate on juvenile blue crabs (Holt 1977, Rott et al. 1998). Such indirect effects can occur over several generations, by high alternative prey densities stimulating growth of the predator population (Settle et al. 1996, Carvalheiro et al. 2008) or, as in the present study, by patch-scale movement of predators (Holt \& Kotler 1987, Brown \& Mitchell 1989, Murakami \& Nakano 2002). Because it operates by the latter mechanism, the predator response in the present study is a short-term effect. Because the relationship here involves cannibalism, it is unclear what the effects would be in the long term because cannibalism will likely reduce future recruitment to the adult stage, which is the predator in the present case.

By combining the predator functional response and aggregative response, we predict that this 2-prey system will exhibit apparent mutualism or short-term apparent competition depending on the prey densities. At low clam densities, the clam presence reduces the predation rate on juvenile blue crabs through a modification of the predator functional response, as observed in our experiments. At high clam densities, although the effect of clams on the functional response continues, the aggregative response of predators results in an increase in the predation rate on juvenile crabs. The non-linear responses that change at different scales interact to produce this result (Abrams \& Matsuda 1996).

It is possible that agonistic interactions among adult crabs might decrease predation rates at high predator densities (e.g. Mansour \& Lipcius 1991, Clark et al. 1999a,b). However, the range of predator density predicted at 0 and 300 clams $\mathrm{m}^{-2}$ by the aggregative response model we used is only 0.12 and $0.27 \mathrm{crabs} \mathrm{m}^{-2}$, whereas experiments examining agonism typically occur at a much higher density range (e.g. 0.5 to $4 \mathrm{crabs}^{-2}$ ) (Mansour \& Lipcius 1991, Kuhlmann \& Hines 2005) or in a field enclosure with crabs competing for small patches of low-density prey (Clark et al. 1999b). Because agonism decreases with increasing prey density and with decreasing predator density (Mansour \& Lipcius 1991, Clark et al. 1999b), we expect that its net effect will be minimal at the highest prey and predator densities used in our field modeling. Indeed, in laboratory experiments, the effect of agonism at $1 \mathrm{crab} \mathrm{m}^{-2}$ on the perpredator predation rates is negligible (Kuhlmann \& Hines 2005). Finally, a field experiment with freeranging predators estimated that agonism resulted in a $\sim 15$ to $20 \%$ reduction in predation rate between treatments (Hines et al. 2009), whereas our model predicts variations in predation on juvenile crabs of more that $95 \%$ with changing densities of clams. Thus, although agonism would likely have an effect in the field, given the small range in predator density predicted, the overall low predator density, and the small effect size relative to the effect size we predict, it is unlikely to change our conclusions.

How frequently indirect effects are density dependent is difficult to estimate. Most studies reporting apparent mutualism or commensalism rely on experiments in which predator densities are controlled and 
which are designed to examine either the predator functional response or predator switching behavior (e.g. Eubanks \& Denno 2000, Webster \& Almany 2002, Rickers \& Scheu 2005). Studies reporting shortterm apparent competition typically rely on experiments in which predators are free to move and alternative prey treatments are often either presence or absence and which are designed to examine the predator aggregative response (e.g. Settle et al. 1996, Rott et al. 1998, Murakami \& Nakano 2002). These studies all leave the possibility of density-dependent indirect effects open. In the only other study to our knowledge that included estimates of both the functional response and the aggregative response of predators, the prey species had a consistent indirect effect on each other (Tschanz et al. 2007). We suggest that several characteristics of a system may make it more likely to show such changes in the indirect effect. First, having a predator species that is highly mobile is probably important because a strong aggregative response is necessary for a switch from apparent mutualism to competition. Second, having one or more of the prey species sessile would also contribute because mobile prey could change their density in response to the predator density and change the overall patterns (Schreiber et al. 2006).

Indirect effects are responsible for up to $60 \%$ of the changes to community structure resulting from experimental manipulations (Menge 1995) but are often under-explored (Kaplan \& Denno 2007). The present study highlights the importance of examining both the predator functional response and the predator aggregative response when considering indirect effects in ecological systems and represents, to our knowledge, the first time that such density-dependent indirect effects have been suggested by experimental data. Indirect effects are, by their nature, non-linear, and the interaction of 2 or more effects is likely to lead to unexpected results (e.g. Abrams \& Matsuda 1996).

Acknowledgements. We thank M. Kramer, K. Chop, M. Goodison, R. Agular, A. Young, and L. Brown-Gordon for help with our experiment. Comments by J. Long, R. Foy, and 6 anonymous reviewers substantially improved the manuscript. Hatchery crabs were provided by Y. Zohar and O. Zmora, University of Maryland, Biotechnology Institute, Center of Marine Biotechnology. Funding for this research came from the NOAA Chesapeake Bay Program Office to the Blue Crab Advanced Research Consortium. W.C.L. was supported by a Marine Science Network Fellowship from the Smithsonian Institution. The findings and conclusions in this paper are those of the authors and do not necessarily represent the views of the National Marine Fisheries Service or NOAA.

\section{LITERATURE CITED}

Abrams P (1987a) Indirect interactions between species that share a predator: varieties of indirect effects. In: Kerfoot WC, Sih A (eds) Predation: direct and indirect impacts on aquatic communities. University Press New England, Hannover, NH, p 38-54

Abrams PA (1987b) On classifying interactions between populations. Oecologia 73:272-281

> Abrams PA, Matsuda H (1996) Positive indirect effects between prey species that share predators. Ecology 77:610-616

Akre BJ, Johnson DM (1979) Switching and sigmoid functional response curves by damselfly naiads with alternative prey available. J Anim Ecol 48:703-720

Baird D, Ulanowicz RE (1989) The seasonal dynamics of the Chesapeake Bay ecosystem. Ecol Monogr 59:329-361

Brown JS, Mitchell WA (1989) Diet selection on depletable resources. Oikos 54:33-43

Burnham KP, Anderson DR (2002) Model selection and multimodel inference: a practical information-theoretic approach, 2nd edn. Springer Science, New York, NY

> Carvalheiro LG, Buckley YM, Ventim R, Fowler SV, Memmott J (2008) Apparent competition can compromise the safety of highly specific biocontrol agents. Ecol Lett 11: 690-700

Chesson J (1989) The effect of alternative prey on the functional response of Notonecta hoffmani. Ecology 70: 1227-1235

Clark ME, Wolcott TG, Wolcott DL, Hines AH (1999a) Foraging and agonistic activity co-occur in free-ranging blue crabs Callinectes sapidus: observation of animals by ultrasonic telemetry. J Exp Mar Biol Ecol 233:143-160

Clark ME, Wolcott TG, Wolcott DL, Hines AH (1999b) Intraspecific interference among foraging blue crabs Callinectes sapidus: interactive effects of predator density and prey patch distribution. Mar Ecol Prog Ser 178: 69-78

Colton TF (1987) Extending functional response models to include a second prey type: an experimental test. Ecology 68:900-912

Dittel AI, Hines AH, Ruiz GM, Ruffin KK (1995) Effects of shallow water refuge on behavior and density-dependent mortality of juvenile blue crabs in Chesapeake Bay. Bull Mar Sci 57:902-916

Eggleston DB, Lipcius RM, Hines AH (1992) Density-dependent predation by blue crabs upon infaunal clam species with contrasting distribution and abundance patterns. Mar Ecol Prog Ser 85:55-68

> Elliott JM (2004) Prey switching in four species of carnivorous stoneflies. Freshw Biol 49:709-720

Eubanks MD, Denno RF (2000) Health food versus fast food: the effects of prey quality and mobility on prey selection by a generalist predator and indirect interactions among prey species. Ecol Entomol 25:140-146

> Everett R, Ruiz G (1993) Coarse woody debris as a refuge from predation in aquatic communities. Oecologia 93: 475-486

Greenwood JJD, Elton RA (1979) Experiments on frequency-dependent selection by predators. J Anim Ecol 48:721-737

Hassell MP, Lawton JH, Beddington JR (1977) Sigmoid functional responses by invertebrate predators and parasitoids. J Anim Ecol 46:249-262

> Heimpel GE, Neuhauser C, Hoogendoorn M (2003) Effects 
of parasitoid fecundity and host resistance on indirect interactions among hosts sharing a parasitoid. Ecol Lett 6:556-566

Hines AH, Comtois KL (1985) Vertical distribution of infauna in sediments of a subestuary of central Chesapeake Bay. Estuaries 8:296-304

Hines AH, Ruiz GM (1995) Temporal variation in juvenile blue crab mortality: nearshore shallows and cannibalism in Chesapeake Bay. Bull Mar Sci 57:884-901

> Hines AH, Haddon AM, Wiechert LA (1990) Guild structure and foraging impact of blue crabs and epibenthic fish in a subestuary of Chesapeake Bay. Mar Ecol Prog Ser 67: 105-126

> Hines AH, Wolcott TG, Gonzalez-Gurriaran E, GonzalezEscalante JL, Freire J (1995) Movement patterns and migrations in crabs: telemetry of juvenile and adult behaviour in Callinectes sapidus and Maja squindo. J Mar Biol Assoc UK 75:27-42

> Hines AH, Long WC, Terwin JR, Thrush SF (2009) Facilitation, interference, and scale: the spatial distribution of prey patches affects predation rates in an estuarine benthic community. Mar Ecol Prog Ser 385:127-135

> Holland AF, Mountford NK, Mihursky J (1977) Temporal variation in upper bay and mesohaline communities: I. The 9-m mud habitat. Chesapeake Sci 18:370-378

Holling CS (1959) The components of predation as revealed by a study of small mammal predation of the European pine sawfly. Can Entomol 91:293-320

Holt RD (1977) Predation, apparent competition, and the structure of prey communities. Theor Popul Biol 12: 197-229

Holt RD, Kotler BP (1987) Short-term apparent competition. Am Nat 130:412-430

Holt RD, Lawton JH (1994) The ecological consequences of shared natural enemies. Annu Rev Ecol Syst 25:495-520

> Johnson EG, Young AC, Hines AH, Bademan M, Kramer MA, Goodison MR, Aguilar R (2011) Comparison of survival and growth of hatchery-reared versus wild blue crabs, Callinectes sapidus Rathbun. J Exp Mar Biol Ecol 402:35-42

- Kaplan I, Denno RF (2007) Interspecific interactions in paytophagous insects revisited: a quantitative assessment of competition theory. Ecol Lett 10:977-994

Kuhlmann ML, Hines AH (2005) Density-dependent predation by blue crabs, Callinectes sapidus, on natural prey populations of infaunal bivalves. Mar Ecol Prog Ser 295: 215-228

> Lester PJ, Harmsen R (2002) Functional and numerical responses do not always indicate the most effective predator for biological control: an analysis of two predators in a two-prey system. J Appl Ecol 39:455-468

Mansour RA, Lipcius RN (1991) Density-dependent foraging and mutual interference in blue crabs preying upon infaunal clams. Mar Ecol Prog Ser 72:239-246

McGaw IJ, Reiber CL (2000) Integrated physiological responses to feeding in the blue crab Callinectes sapidus. J Exp Biol 203:359-368

> Menge BA (1995) Indirect effects in marine rocky intertidal interaction webs: patterns and importance. Ecol Monogr 65:21-74

Murakami M, Nakano S (2002) Indirect effect of aquatic insect emergence on a terrestrial insect population through by birds predation. Ecol Lett 5:333-337
Murdoch WM (1969) Switching in general predators: experiments on predator specificity and stability of prey populations. Ecol Monogr 39:335-354

Oaten A, Murdoch WM (1975) Functional response and stability in predator-prey systems. Am Nat 109:289-298

Orth RJ, van Monfrans J (1987) Utilization of a seagrass meadow and tidal marsh creek by blue crabs Callinectes sapidus. 2. Seasonal and annual variations in abundance with emphasis on post-settlement juveniles. Mar Ecol Prog Ser 41:283-294

Quinn GP, Keough MJ (2002) Experimental design and data analysis for biologists, 1st edn. Cambridge University Press, Cambridge

Rickers S, Scheu S (2005) Cannibalism in Pardosa palustris (Araneae, Lycosidae) effects of alternative prey, habitat structure, and density. Basic Appl Ecol 6:471-478

Rott AS, Muller CB, Godfray HCJ (1998) Indirect population interactions between two aphid species. Ecol Lett 1: 99-103

Schreiber SJ, Lipcius RN, Seitz RD, Long WC (2006) Dancing between the devil and the deep blue sea: the stabilizing effect of enemy-free sinks and victimless sinks. Oikos 113:67-81

Seitz RD, Lipcius RN, Hines AH, Eggleston DB (2001) Density-dependent predation, habitat variation, and the persistence of marine bivalve prey. Ecology 82:2435-2451

Seitz RD, Lipcius RN, Stockhausen WT, Delano KA, Seebo MS, Gerdes PD (2003) Potential bottom-up control of blue crab distribution at various spatial scales. Bull Mar Sci 72:471-490

Seitz RD, Lipcius RN, Knick KE, Seebo MS, Long WC, Brylawski BJ, Smith A (2008) Stock enhancement and carrying capacity of blue crab nursery habitats in Chesapeake Bay. Rev Fish Sci 16:329-337

Settle WH, Ariawan H, Astuti ET, Cahyana W and others (1996) Managing tropical rice pests through conservation of generalist natural enemies and alternative prey. Ecology 77:1975-1988

Svenning MA, Borgstrøm R, Behli TO, Moen G, Barrett RT, Pedersen T, Vader W (2005) The impact of marine fish predation on Atlantic salmon smolts (Salmo salar) in Tana estuary, North Norway, in the presence of an alternative prey, lesser sandeel (Ammodytes marinus). Fish Res 76:466-474

Taylor DL, Eggleston DB (2000) Effects of hypoxia on an estuarine predator-prey interaction: foraging behavior and mutual interference in the blue crab Callinectes sapidus and the infaunal clam prey Mya arenaria. Mar Ecol Prog Ser 196:221-237

Tschanz B, Bersier LF, Bacher S (2007) Functional responses: a question of alternative prey and predator density. Ecology 88:1300-1308

> Virnstein RW (1977) The importance of predation by crabs and fishes on benthic infauna in Chesapeake Bay. Ecology 58:1199-1217

> Webster MS, Almany GR (2002) Positive indirect effects in a coral reef fish community. Ecol Lett 5:549-557

> Wootton JT (1994) The nature and consequences of indirect effects in ecological communities. Annu Rev Ecol Syst 25:443-466

> Zmora O, Findiesen A, Stubblefield J, Frenkel V, Zohar Y (2005) Large-scale juvenile production of the blue crab, Callinectes sapidus. Aquaculture 244:129-139 